\title{
HISPID POCKET MICE IN TALLGRASS PRAIRIE: ABUNDANCE, SEASONAL ACTIVITY, HABITAT ASSOCIATION, AND INDIVIDUAL ATTRIBUTES
}

\author{
Glennis A. Kaufman ${ }^{1,2}$, Dawn M. Kaufman ${ }^{1}$, and Donald W. Kaufman ${ }^{1}$
}

Aвstract.-Hispid pocket mice (Chaetodipus hispidus) are found from the grasslands of the Great Plains to the deserts of the southwestern United States, but the natural history and ecology of this species have not been described in native tallgrass prairie at the eastern edge of its range. We initiated an ongoing long-term study of small mammals on Konza Prairie Biological Station, Kansas (a Long-Term Ecological Research [LTER] site), in autumn 1981. Our sampling scheme for 14 LTER sites was a 20-station trapline; small mammals were sampled in autumn and spring for 30 years and in summer for a shorter period. We combined data for these sites with those from shorter studies on Konza Prairie that used traplines and trapping grids. We recorded only 96 hispid pocket mice over the 30 years of study $(>300,000$ trap-nights overall). Pocket mice were more likely to be captured in autumn and summer than in spring. The earliest annual capture was on 20 March and the latest on 7 December; males emerged from torpor in spring before females, whereas females entered torpor later in autumn. Precipitation (January-September) had a tight limiting effect on maximal number of individuals that were present in autumn. Pocket mice were more common on slope prairie than on upland or lowland prairie, but burning and grazing had no effect. Their spatiotemporal distribution showed a slightly "anti-nested" pattern with only weakly preferred sites and no focal years that might indicate favorable conditions. Collectively, our data suggested the presence of 3 age classes when individual body masses (no differences between males and females) were plotted against capture date. Finally, our study illustrates the importance of long-term data sets, especially in the study of uncommon to rare species.

RESUMEN.-El ratón de bolsa híspido (Chaetodipus hispidus) se encuentra desde los pastizales de las Grandes Llanuras hasta los desiertos del suroeste de los Estados Unidos, pero la historia natural y la ecología de esta especie no se ha descrito en las praderas nativas de gramíneas altas en el borde este de su distribución. Iniciamos un estudio continuo a largo plazo de pequeños mamíferos en la Estación Biológica de la Pradera de Konza, en Kansas (un sitio de investigación ecológica a largo plazo [Long-Term Ecological Research, LTER]) en el otoño de 1981. Nuestro esquema de muestreo para los 14 sitios LTER fue una línea de trampas de 20 estaciones. Durante 30 años se muestrearon mamíferos pequeños en otoño y primavera, y en verano se muestrearon por un período más corto. Combinamos los datos de estos sitios con aquellos de estudios más breves en la Pradera de Konza que utilizaron líneas de trampas y trampas de rejillas. Registramos sólo 96 ratones de bolsa híspidos durante los 30 años de estudio (más de 300,000 noches de trampas en total). Estos ratones tuvieron mayores posibilidades de ser atrapados en otoño y verano que en primavera. La primera captura anual fue el 20 de marzo y la última el 7 de diciembre; en primavera los machos despertaban del letargo antes que las hembras, mientras que en otoño las hembras entraban en letargo después que los machos. La precipitación (enero a septiembre) tuvo un fuerte efecto limitante en la cantidad máxima de individuos presentes en otoño. Los ratones eran más comunes en praderas de pendiente que en praderas de tierras altas o tierras bajas, pero la quema y el pastoreo no tuvieron efecto. Su distribución espacio-temporal reveló un patrón ligeramente "anti-anidado" con sitios débilmente preferidos y sin años focales que pudieran indicar condiciones favorables. De manera conjunta, nuestros datos sugieren la presencia de 3 clases de edad cuando se graficó la masa corporal de los individuos (sin diferencias entre machos y hembras) contra la fecha de captura. Finalmente, nuestro estudio demuestra la importancia de los conjuntos de datos de largo plazo, especialmente en el estudio de especies poco comunes a raras.

The hispid pocket mouse (Chaetodipus hispidus) is found from the grasslands of the Great Plains (South Dakota into Mexico) to the deserts of the southwestern United States (Paulsen 1988, Schmidly et al. 1993). In Kansas, this granivorous rodent inhabits prairies and occurs throughout the state, except for the eastern edge (Schmidly et al. 1993). This mouse is most common in the western portion of
Kansas (Bee et al. 1981), where mixed grass, short grass, and sagebrush prairies occur. Likewise, most studies of the hispid pocket mouse in Kansas have occurred in north-central and western portions of the state, and therefore, the natural history and ecology of this mouse have not been described in tallgrass prairie (e.g., the Flint Hills). The mesic conditions, which occur in tallgrass prairies, result in high 
annual net primary productivity and soil surfaces that are covered by plant litter and debris (Knapp et al. 1998a). These mesic conditions contrast with those of arid grasslands in Kansas; however, patterns observed in mixed grass and short grass prairies as well as agricultural lands might be instructive relative to patterns that might be expected in tallgrass prairie.

Mixed and short grass prairies provide relatively short and sparse vegetative cover (e.g., Armstrong 1972, Kaufman and Fleharty 1974, Moulton et al. 1981), sites with relatively open soils, and readily available grass and forb seeds. Hispid pocket mice often use areas of sandy soils (e.g., sandy grassland sites in north-central Kansas: Kaufman et al. 2000a; western and southwestern Kansas: Choate and Fleharty 1975, Fleharty and Navo 1983), but they also occur in loamy upland sites and rocky breaks sites (e.g., Blair 1937, Kaufman and Fleharty 1974, Kaufman and Kaufman 1989, 1990, 2000, Kaufman et al. 1995, 2000a). These heteromyids also can become locally common in sandy and loamy croplands where much of the soil surface is open and both crop and weed seeds provide abundant food resources (e.g., Fleharty and Navo 1983, Kaufman and Kaufman 1989, 1990).

In autumn 1981, we initiated a long-term study of small mammals to assess both temporal and spatial variation in their abundance in native tallgrass prairie on the Konza Prairie Biological Station in northeastern Kansas. We assumed that this large pocket mouse would be present on Konza Prairie because of its statewide distribution in prairies (Bee et al. 1981), but we also assumed that it was unlikely to be spatially widespread or numerically abundant across the rolling landscape (i.e., limestone benches and slopes) of the Flint Hills (Oviatt 1998). Spatially, we expected a positive association especially with rocky sites (i.e., limestone breaks at crests of hills and contiguous upland above and slopes below breaks) as compared to upland and lowland sites (Kaufman et al. 1995). Limestone breaks and other steep rocky areas are relatively arid, open, and covered with sparse herbaceous vegetation, even within this mesic environment.

To further understand the temporal and spatial patterns in abundance of hispid pocket mice, we examined whether year-to-year variation in their abundance was driven by temporal variation in weather (e.g., precipitation). If a relationship existed, we expected these mice to be more abundant in dry years than in wet to very wet years (Windberg 1998). Furthermore, because large mammalian grazers can create open and sparse vegetative cover, we wanted to understand whether bison grazing and prairie fires (also known as "red buffalo"-a name given to prairie fire by tribes of plains Indians before European settlement) influenced the spatial distribution or temporal variation in abundance of pocket mice. We also explicitly assessed the spatiotemporal distribution (via nested subset analysis) to understand whether this heteromyid occupied tallgrass prairie in a predictable fashion (e.g., preferentially occupying sites or years that represented favorable conditions). This analysis might be particularly informative at the edge of the species' range, where favorable conditions likely are rarer overall than at sites in the center of the species' range. At the edge, it is more likely that sites are consistently low in abundance, varying between those that are habitable at low levels to those that are uninhabitable (e.g., Brown 1984, Brown et al. 1995, 1996). Predictability of species presence, or lack thereof, could have implications for conservation. Finally, demographic factors, such as sex ratio, reproductive activity, and body size distribution (Paulsen 1988, Eisenberg 1993, Jones 1993), as well as seasonal activity can affect the number of individuals observed. Thus, we have explored whether these factors are important in the life history patterns observed for this mouse.

\section{Methods}

Study Area

Our study was conducted on the Konza Prairie Biological Station $\left(39^{\circ} 05^{\prime} \mathrm{N}, 96^{\circ} 35^{\prime} \mathrm{W}\right)$, which is a 3487 -ha experimental research site located near Manhattan, Kansas (described in Finck et al. 1986). The predominant type of vegetation on Konza Prairie is native tallgrass prairie, although a small portion of the site has gallery forest and to a lesser extent small old fields and planted brome fields, which are undergoing plant succession, and a few small crop fields. Dominant prairie grasses are big bluestem (Andropogon gerardii Vitman), Indiangrass (Sorghastrum nutans [L.] Nash), and switchgrass (Panicum virgatum L.; Freeman 
TABLE 1. Experimental manipulations applied to the 7 long-term ecological research (LTER) units in native tallgrass prairie on Konza Prairie Biological Station, Kansas. Each unit was sampled by 2 standard traplines from autumn 1981 through spring 2011 and in summer from 1982 through 1987. Treatment units are arranged from the greatest to fewest total number of spring fires. Grazing by bison (Bos bison), if it occurred, began in summer 1992. Trapping effort is number of total trap-nights in each season.

\begin{tabular}{lccccc}
\hline & & & \multicolumn{2}{c}{ Trapping effort } \\
\cline { 4 - 6 } LTER sites $^{\text {a }}$ & Number of fires & Grazing & Autumn & Spring & Summer \\
\hline 001D & 30 & No & 9600 & 9600 & 1920 \\
N01B & 23 & Yes & 9600 & 9600 & 1920 \\
004F & 10 & No & 9600 & 9600 & 1920 \\
004B & 9 & No & 9600 & 9600 & 1920 \\
N04D & 7 & Yes & 9600 & 9600 & 1920 \\
N20B & 2 & Yes & 9600 & 9600 & 1920 \\
020B & 1 & No & 9600 & 9600 & 1920 \\
\hline
\end{tabular}

aThe first character in treatment designation represents grazed $(\mathrm{N})$ or ungrazed $(0)$, and second and third characters represent the planned fire frequency interval (e.g., 01 indicates that treatment is burned annually).

1998). Topography on Konza Prairie includes lowlands and flat-topped uplands and stairstep terraces that have resulted from differential erosion of shale and limestone strata (Oviatt 1998). The site is divided into $>50$ firegrazer treatment units (16-133 ha in size) that are experimentally burned, mostly in spring, and have fire-return intervals of 1 to $>20$ years (Fig. 1.5 [p. 8] in Knapp and Seastedt 1998 for map of Konza). Some experimental burn sites are grazed throughout the year by bison (Bos bison).

\section{Field Methods}

Fires generally were conducted in April so that our research year involved sampling in summer (typically in July; about 3 months after fire), autumn (typically October; 6-7 months after fire), and spring (typically in March; 10-11 months after fire). For our longterm efforts, we sampled small mammals by using traplines. Our standard traplines were 20 stations in length with $15 \mathrm{~m}$ between stations; traplines typically were placed across the topographic features present (i.e., uplands, slopes, and lowlands) and trapped for 4 consecutive nights during each season. We also sampled small mammals by grids that varied in trapping design and size because of fire boundaries and habitat types available, but we always maintained the 15-m spacing between trap stations. Number of consecutive nights trapped within trapping sessions and intervals between trapping sessions also varied and depended on the goals of each study.

We placed 2 large, nonfolding Sherman live traps $(7.6 \times 8.9 \times 22.9 \mathrm{~cm})$ baited with peanut butter and rolled oats (Kaufman et al. 1988) at each station along traplines during each trapping session. On the large trapping grid in prairie $(24 \times 24$ grid $)$, only peanut butter was used as a bait in summer. Only one trap was placed at a station on some grids. During autumn and spring, polyester fiberfill was used as nesting material in each trap. Mammals were marked individually with toe-clips from spring 1981 through spring 1990. After spring 1990, they were marked with hair-clips (small patch of fur shaved with a battery-powered moustache clipper at specific locations in the dorsal pelage) such that individuals captured earlier in a particular trap period could be recognized but were not individually identifiable. We recorded sex, age, and reproductive status (females only) of individuals during each capture, as well as body mass at the initial capture of each small mammal in a survey period.

\section{Sampling Surveys}

LONG-TERM ECOLOGICAL RESEARCH (LTER) SITES IN PRAIRIE.-Beginning in autumn 1981, we initiated an ongoing survey of rodents and shrews in 7 permanent experimental treatments, which varied in fire and grazing histories (Table 1). The number of spring fires ranged from 1 on 020B (long-term unburned) to 30 on 001D (burned annually). Three experimental treatments occurred within a large fenced area where bison could graze throughout each year since the summer of 1992; level of grazing was spatially and temporally variable. Based on visual assessments, portions of survey traplines in N01B, N04D, N20B, and 004B were set across sharp, rocky breaks and continued down into contiguous steep, rocky hillslopes below the breaks. Remaining survey lines in 
001D, 004F, and 020B had less defined breaks, many fewer rocks, and shallow hillslopes.

During each survey, we set traps on 2 permanent traplines in each of the 7 treatment units (hereafter, LTER Core sites or lines) from autumn 1981 to present, as well as summers from 1982 through 1987 (Table 1). Only one of the paired traplines (selected at random) within each of the 7 treatment units was sampled in the first trapping session each season; the remaining 7 survey lines were trapped in a second trapping period. Our trapping effort over the 30 years of study was $>145,000$ trap-nights.

ADDITIONAL PRAIRIE SITES.-During autumn 1981 through spring 2011, we also sampled small mammals for shorter periods of time at other prairie sites by using our standard traplines (Table 2). The fire history varied on these sites, but none of these sites was grazed by bison. Some treatment units had spring fires that had fire-return intervals of $1,2,4$, or 10 years (non-LTER; Table 2), whereas other treatment units had annual fires that occurred in fall, winter, or spring or had biennial fires in summer (seasonal; Table 2). We also trapped in treatment units that had a change in burning regime (reversal; Table 2). In 2000, a unit that had been burned annually was reversed to an unburned unit; a second unit that abutted the first unit was reversed from an unburned to an annually burned unit. Finally, we also sampled small mammals from March through October on 2 grids, the Hulbert plots and prairie grid (Table 2), which varied in fire history, but were not grazed by bison. The Hulbert plots were placed across a shallow slope and contained an array of small experimental plots; some of these were left unburned and others had spring, summer, or fall fires at a 1year or 4-year interval. The prairie grid $(24 \times$ 24 stations) was set across 2 sharp breaks and the contiguous steep rocky slope below each of the breaks sites. The fire regime on this large grid primarily consisted of two 4-year spring burns that occurred in different years. All sampling efforts in prairie including LTER and non-LTER traplines and grids resulted in $>320,000$ trap-nights (Tables 1, 2); time periods of trapping were from late February into the first part of December.

BRome FIELDS.-We surveyed small mammals in planted brome fields from autumn 1981 through autumn 1987 (Table 2). The 2 traplines occurred in different treatment units that had different fire regimes. One unit had 5 spring fires, whereas the other had only 2. Smooth brome (Bromus inermis Leyss.) was the predominant vegetation, but a variety of other grasses and forbs was present.

WOODLAND HABITATS.-We sampled small mammals in 3 woodland areas from 1981 through 1993 (Table 2). The woodland and outcrops habitat included 2 woodland and 2 woodland outcrop standard traplines that were associated with Kings Creek. The other 2 habitats were also associated with Kings Creek; the woodland was a gallery forest that had a large irregularly shaped rectangular grid, whereas the other grid was set in a mixed woodland-grassland area.

\section{Statistical Methods and Analyses}

Only the LTER Core lines were used to examine temporal variation in abundance and patterns of habitat association of hispid pocket mice. We used percent coefficient of variation $(\mathrm{CV})$ to characterize temporal variation (Kaufman and Kaufman 2000) in autumn abundance over 30 years. We used chi-square analysis $\left(\chi^{2}\right)$ to determine whether number of pocket mice varied by season (summer, autumn, and spring). Expected values were based on the trapping effort in each season. We also examined whether precipitation could serve as a driver of the number of pocket mice present annually in autumn on LTER Core sites. We examined precipitation during 3 time periods: summer (June-August), growing season (MarchAugust), and annual (January-September) in the current year. Visual inspection of the plot of autumn abundance against current year precipitation ( $\mathrm{mm}$; January-September) suggested amount of precipitation as a limiting factor for the maximal number of pocket mice that could be present in any given autumn. We fitted a least-squares regression line to the maximal precipitation at which we observed an abundance class (from 1 to 4 pocket mice).

We also assessed habitat association by examining the number of individuals captured in the 3 topographic positions (uplands, slopes, and lowlands). Expected values in the $\chi^{2}$ analysis were based on trapping efforts in each topographic position. We used a log-likelihood test $(G$ test) to determine whether grazing by bison had an effect on abundance of hispid pocket mice. To do this, we used only 8 survey 


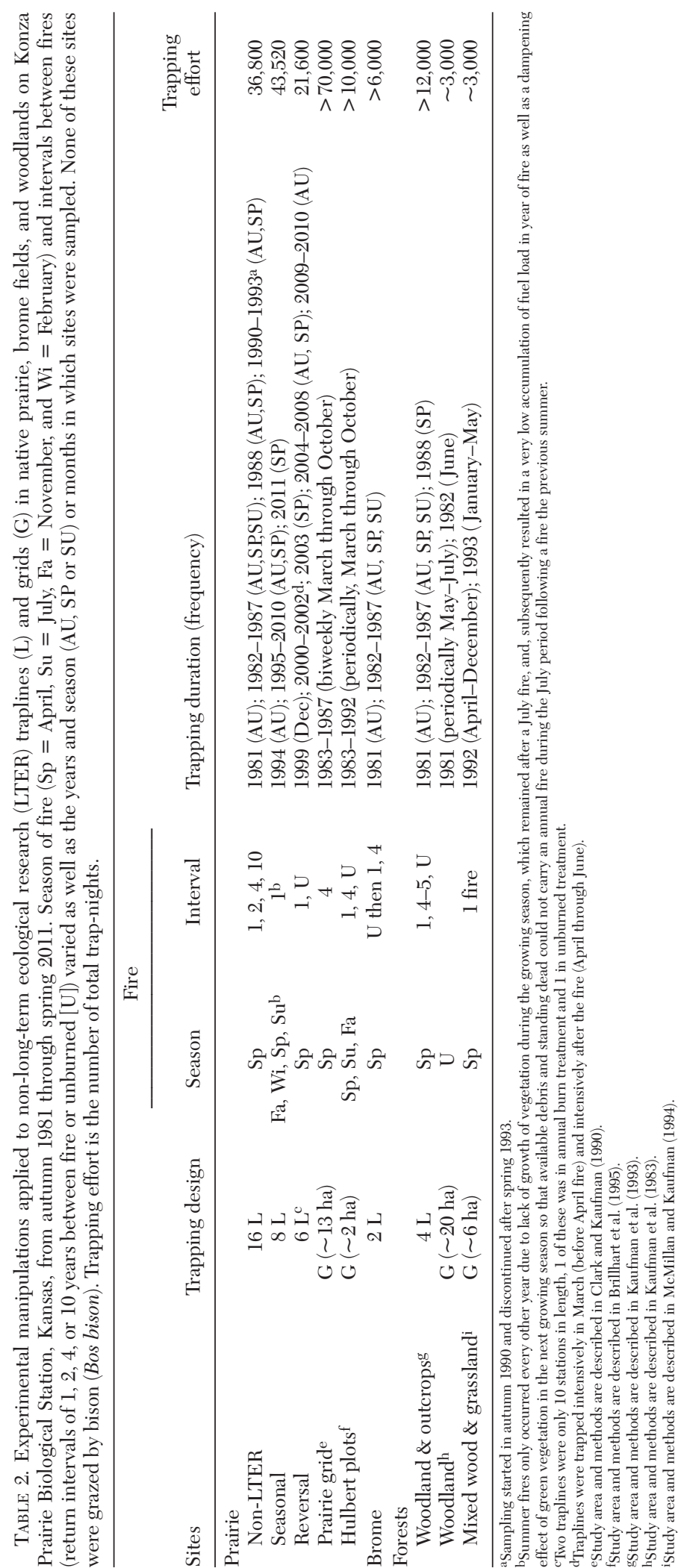


lines that had strong breaks and rocky slopes. We compared the proportion of individuals captured in autumn from 1981 to 1992 and 1993 to 2010. During the first period, bison grazed on none of the 8 survey lines, whereas during the second period, bison could graze on N01B, N04D, and N20B lines, but not on 004B. We determined whether the proportions changed on grazed lines compared to 004B in these 2 time periods.

In contrast to the abundance and habitat association analyses, all individuals captured during the 30 years were used in analyses of sex ratio and body size. The exceptions were that body mass was not recorded for 4 individuals in prairie sites, and sex and mass were not available for 9 individuals on the mixed woodland-grassland grid. We used $\chi^{2}$ analysis to test whether our overall sample exhibited a 1:1 sex ratio. The Yates correction (Zar 1974) was applied because degrees of freedom equalled 1 for the test. If we did not reject the null hypothesis (i.e., 1:1 ratio), we then computed the margin of error $(1.96 * \sqrt{ }(p(1-p) / n)$, where $p$ is the proportion of males and $n$ is the sample size, to assess the strength of the test. We also tested whether sex ratios varied among seasons by using a $\chi^{2}$ contingency table analysis.

We examined the body mass distribution of males and females across 2 data sets. In the first set, we used a one-way analysis of variance to test whether males and females differed in body size across the overall sample. In the second data set, we restricted our analysis to those individuals that were $\geq 35$ g, as we assumed that this sample represented individuals of adult size (35-40 g, Jones et al. 1985). We report the mean \pm 1 SE. Then, we graphically explored the distribution of body sizes and growth patterns in hispid pocket mice because we were interested in how body masses were distributed across the seasons and if these patterns might reveal "age" classes. To examine seasonal patterns of body mass, we used data from all individuals that were captured and weighed, as well as multiple records of a few mice (2-4 masses per individual) captured during different trapping periods on the large prairie grid. Individuals usually changed body mass over a 2 -week or greater period of time between capture. We also used information on body masses and capture dates for 12 individuals that were captured 2-4 times (29 masses and dates in total) to initiate the graphical assessment of temporal changes in body size. We then combined information on body mass for these mice with dates of individuals captured only once (total sample size was 98). Subsequently, we visually examined the occurrence of breaks in patterns of body masses relative to Julian dates of capture to estimate yearly age classes of captured mice. It appeared that we had 3 "age" classes present within our data set; we fit a leastsquares linear regression to each of the 2 younger age classes to suggest a "potential" growth pattern across an annual period. The number of individuals in the third age class was too small for further analysis.

We examined the spatiotemporal distribution of hispid pocket mice on Konza Prairie by using nested subset analysis to analyze presence-absence data from autumns over the 30 years for the 14 LTER Core traplines. This technique utilizes Monte Carlo simulation to determine if the observed distribution of pocket mice is more ordered, or predictable, than expected by random chance, and it incorporates the actual spatiotemporal rarity (or commonness) of a species in the generation of random expectations for a species' distribution. We analyzed these differences using the Nestedness Temperature Calculator (Atmar and Patterson 1995), which equates order to temperature ( $T$ in degrees) with "colder" matrices being more ordered in a nested subset manner. A nested subset pattern of occurrences within a space-time matrix is one in which individuals in years with few captures tend to be restricted to a few sites where they also would be captured in years when they were abundant and trapped in many sites (Kaufman et al. 2000b). In other words, more favorable habitats will be occupied before those that are less hospitable; likewise, pocket mice are more likely to be present in years with favorable conditions than in those that are less suitable. If the observed spatiotemporal distribution of a species is significantly nested, the distribution matrix displays an obvious "triangular" pattern of occurrence (representing captures) filled from the upper left corner. If the "temperature" of the observed matrix is cold enough in comparison to the randomized data, the distributional pattern is significantly nested, indicating that species occurrence is relatively predictable in terms of site-years. Spatiotemporal analyses of this 
type, along with more direct assessments of the effects of environmental characteristics on presence and abundance, allow us to assess whether a rare species occurs in a predictable fashion at the edge of its range.

\section{Results}

We recorded 96 hispid pocket mice from summer 1981 through spring 2011. Of these, 35 were captured on the 14 LTER Core traplines and 20 on the prairie traplines. We also captured 26 individuals on the prairie grid, 9 on the mixed grassland-woodland grid (79\% of captures were in grassland habitat), 5 on the Hulbert plots, and 1 on the 2 limestone outcrop traplines, which had sparse woody vegetation at the interface of prairie. No pocket mice were captured on brome traplines, 2 woodland traplines, or the woodland grid.

\section{Seasonal Aboveground Activity}

The earliest annual captures occurred on 20 March in both 1987 and 1991 and latest capture on 7 December in 1991. We captured 3 hispid pocket mice during our early sampling period (late February into early April; $>100,000$ trap-nights), but those captures only occurred in late March $(n=2)$ and early April $(n=1)$. Aboveground activity then increased as 9 individuals were captured in late April and early May, even though our trapping effort was much lower ( $<30,000$ trap-nights). We captured 40 pocket mice from early to late October (>100,000 trap-nights), 7 from early to late November $(<25,000$ trap-nights), and 1 in early December $(\sim 1000$ trap-nights) before aboveground activity ceased.

\section{Abundance}

RELATIVE ABUndancE.-For the 14 LTER Core sites, 0.005 individuals were captured per trapline in spring ( 2 hispid pocket mice, 420 traplines), 0.071 in summer $(6,84)$, and 0.064 in autumn $(27,420)$. These mice were more likely to be captured during summer and autumn than in spring $\left(\chi^{2}=22.4, \mathrm{df}=2, P=\right.$ $0.00001)$. This pattern did not change when the 55 pocket mice captured on all prairie traplines were included $\left(\chi^{2}=31.0, \mathrm{df}=2, P\right.$ $<0.00001$ ); abundances were 0.006 (4 mice, 696 traplines), $0.056(9,160)$, and 0.060 (42, $705)$ mice per trapline in spring, summer, and autumn, respectively.
INTERANNUAL VARIATION IN OCCURRENCE.Hispid pocket mice were captured during 18 of 30 autumns, 2 of 30 springs, and 4 of 6 summers in our 14 LTER Core sites. Abundance in autumns demonstrated no unidirectional change over time (Fig. 1); interannual variation in autumn abundances was high over the 30 years $(C V=114 \%)$. We found no direct relationship between number of individuals captured in autumn and precipitation (i.e., summer [June-August], growing season [MarchAugust], or annual precipitation [January-September]). However, annual precipitation had a limiting effect on the maximal number of individuals present in autumn $\left(R^{2}=0.98, F_{1,3}=\right.$ 82.2, $P=0.012$; Fig. 2 ). As annual precipitation increased from $600 \mathrm{~mm}$, the maximal number of hispid pocket mice decreased from 4 individuals; 1 potential individual was lost for $\sim 135 \mathrm{~mm}$ of added precipitation $(y=8.34$ $-0.0072 x$, where $x$ is January-September precipitation in $\mathrm{mm}$ and $y$ is number of pocket mice). Abundances in spring and summer were too limited for analyses.

INFLUENCE OF TOPOGRAPHY, GRAZERS, AND FIRE.-Individuals captured in autumn were associated differentially with topographic features $\left(\chi^{2}=74.3, \mathrm{df}=2, P<0.00001\right)$ on the 14 LTER Core sites; hispid pocket mice were associated strongly with slopes (1.90 mice per 100 trap-nights) in contrast to lowland and upland $(0.15$ and 0.05 mice per 100 trapnights, respectively). When individuals captured in summer and spring were combined with those in autumn, differential association remained highly significant for topographic position on the Core lines $\left(\chi^{2}=69.3, \mathrm{df}=2\right.$, $P<0.00001)$. Likewise, we found a strong positive association with slope prairie (2.17 mice per 100 trap-nights) compared to use of lowland and upland prairie $(0.21$ and 0.18 mice per 100 trap-nights, respectively). On the prairie grid, pocket mice also were associated positively with slope prairie $\left(\chi^{2}=12.4\right.$, $\mathrm{df}=2, P=0.002)$; we captured 1.18 mice per 10 stations on slopes, 0.75 mice per 10 stations in uplands, and 0.21 mice per 10 stations in lowlands.

The association between hispid pocket mice and slopes is further supported by the specific treatments where these mice were present; $94 \%$ (33 of 35) of mice captured in all seasons and 96\% (26 of 27) of individuals captured in autumn occurred on the 8 LTER 


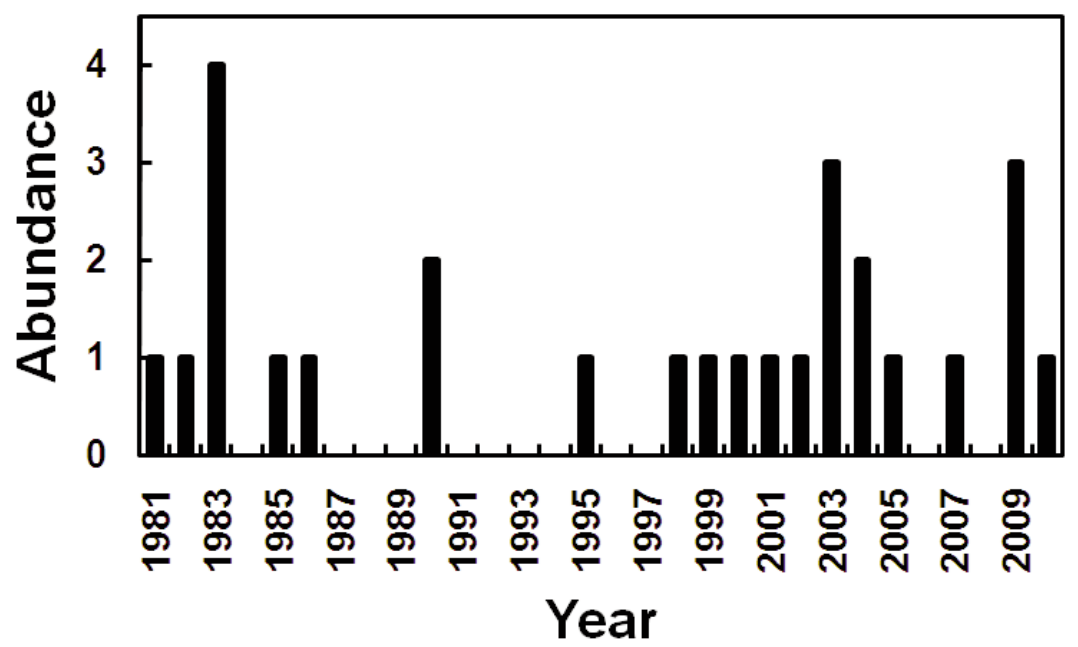

Fig. 1. Number of hispid pocket mice (Chaetodipus hispidus) captured in autumn through time on Konza Prairie Biological Station, Kansas, on 14 LTER Core traplines during 1981-2010.

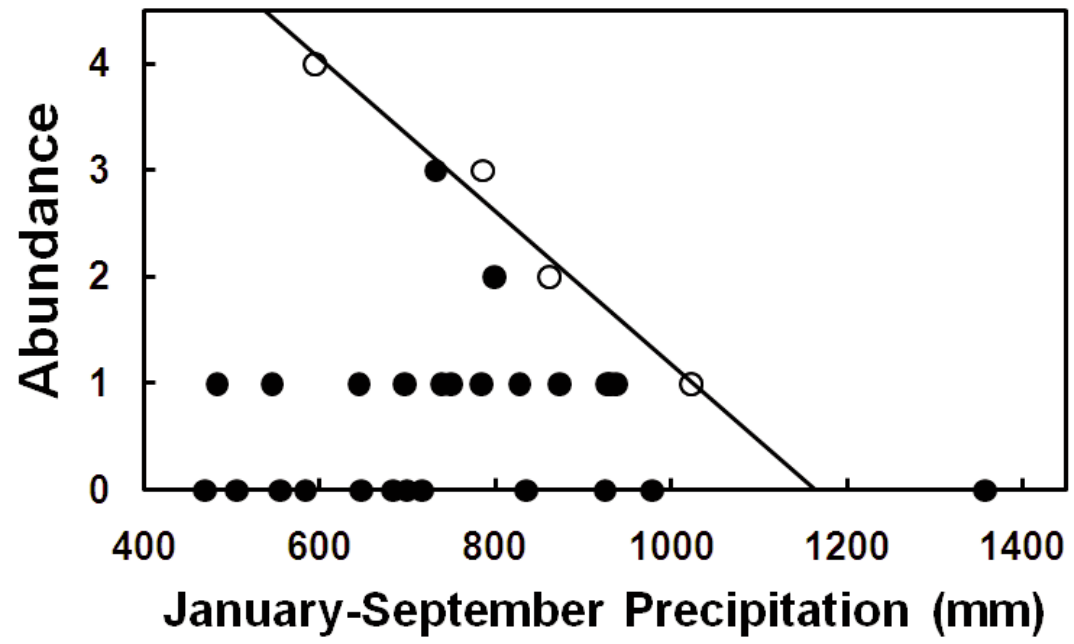

Fig. 2. Number of hispid pocket mice (Chaetodipus hispidus) captured in autumn relative to January-September precipitation in current year on Konza Prairie Biological Station, Kansas, on 14 LTER Core traplines during 1981-2010. The line represents a tight limiting effect $\left(R^{2}=0.98\right)$ on the maximal precipitation (open circles) at which an abundance class (from 1 to 4 individuals) can be observed in tallgrass prairie.

Core lines that had sharp rocky breaks at the edges of hills and contiguous steep rocky slopes below the breaks of the hills. Captures of 26 hispid pocket mice on the prairie grid also likely were related to rocky breaks and steep rocky slopes included in the area of the grid.

Grazing by bison appeared to have no effect on the presence of hispid pocket mice. Proportions of individuals captured in autumn before and after the addition of bison did not differ significantly from the proportions observed on 004B (which remained ungrazed) during these 2 time periods $(G=0.078, \mathrm{df}=$ $1, P=0.78)$. Congruent with this observation, only 3 of the 12 pocket mice captured in the native grazer area in autumn occurred at stations where bison had grazed. Therefore, the majority $(75 \%)$ of them occurred at stations where bison had not grazed. 
The presence of fire appeared to have no effect on the presence of hispid pocket mice. Abundance in autumn was similar between burned (0.08 mice per trapline) and unburned prairie (0.06 mice per trapline). Likewise, abundance of pocket mice within an autumn also was similar between burned and unburned prairie (burned > unburned: 11 autumns; unburned > burned: 8 autumns); no pocket mice were captured in the 11 remaining autumns.

\section{Spatiotemporal Distribution of Captures}

The 27 hispid pocket mice captured in autumn on the 14 LTER Core sites were recorded in 26 of the possible 420 siteautumns surveys, including 9 sites and 18 autumns (Table 3). We did not find any focal area of spatiotemporal occurrence; only a single pocket mouse was captured in any autumn (among all possible sites), except one (2004; Table 3). Likewise, all pocket mice were captured at different sites, except 2 mice that were captured at a slope station (N01B) in different years. The 26 site-autumns in which pocket mice occurred were not spatiotemporally nested ( $\left.T=44^{\circ}, P=0.98\right)$, but exhibited a slightly "anti-nested" distribution. Ultimately, the nested subset analysis revealed little useful predictability in the spatiotemporal distribution. Pocket mice showed only a moderate preference for 3 of 14 Core sites, in combination with a great deal of spatial and temporal variability (Table 3).

\section{Sex Ratio}

Overall, sex ratio of pocket mice, for which sex was determined $(n=87)$, did not differ from $1: 1\left(47 \%\right.$ male; $\chi^{2}=0.18, \mathrm{df}=1, P=$ 0.67 ; margin of error $=10.5 \%)$. Among seasons, however, sex ratios differed $\left(\chi^{2}=9.1\right.$, df $=2, P=0.011)$. Sex ratios were male biased in spring (March-May, 12 individuals, $83 \%$ males), even in summer (June-August, 25 individuals, $52 \%$ males), and female biased in autumn (September-early December, 55 individuals, $36 \%$ males).

\section{Body Mass}

Of 82 hispid pocket mice whose body masses were available, ranges in body size were 16-81 g for 39 males and 12-72 g for 43 females (Fig. 3). The only pregnant female recorded weighed 49 g. Overall, males were

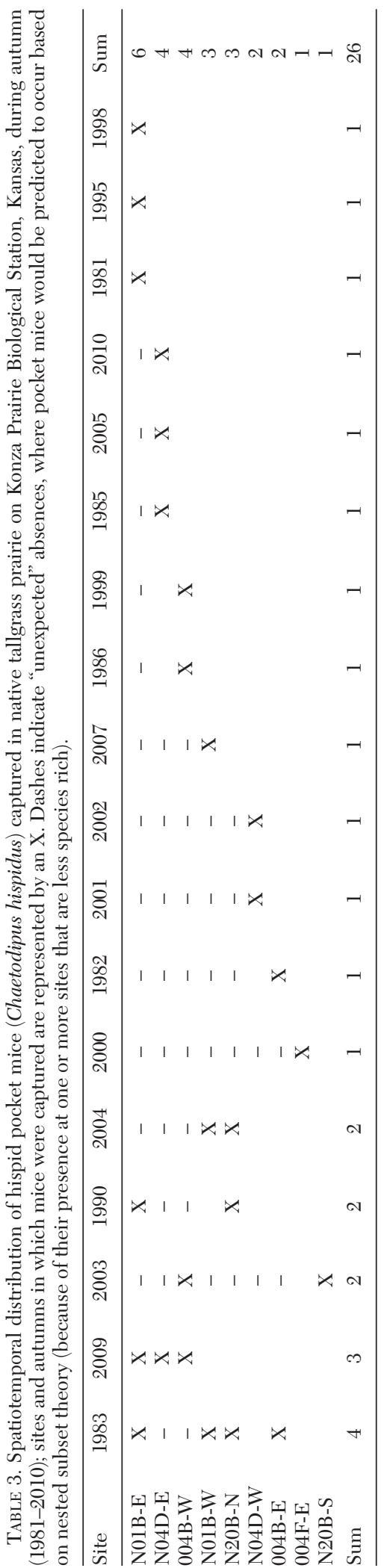




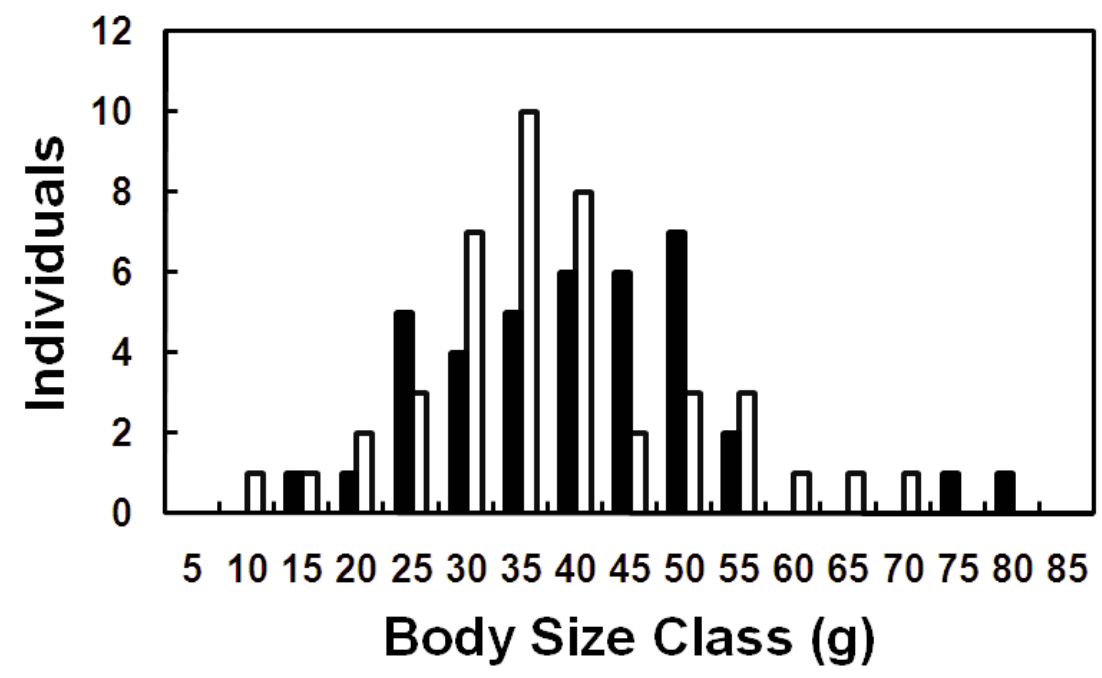

Fig. 3. Distribution of body sizes of male and female hispid pocket mice (Chaetodipus hispidus) captured on Konza Prairie Biological Station, Kansas, from autumn 1981 through spring 2011. Males are shown as closed bars and females as open bars. Numbers on the $\mathrm{x}$-axis represent the lower limit of each 5-g class.

slightly larger $(42.7 \mathrm{~g} \pm 2.1)$ than females $(39.9 \mathrm{~g}$ $\pm 2.0)$, but this difference was not significant $\left(F_{1,80}=0.93, P=0.34\right)$. When we restricted the data set to adult size $(\geq 35 \mathrm{~g})$, males still were slightly larger $(48.4 \mathrm{~g} \pm 2.0)$ than females (46.1 $\mathrm{g} \pm 2.0)$, but this difference was not significant $\left(F_{1,55}=0.67, P=0.42\right)$. Variance was homogeneous for 3 different measures (e.g., Levene: $P=0.81$; O’Brien: $P=0.81$; Brown and Forsythe: $P=0.66$ ). Eleven of 14 individuals that weighed $<30 \mathrm{~g}$ were captured during 18 June-6 August, and 3 were recorded 28 September-28 October (Fig. 4). In contrast, large pocket mice $(>45 \mathrm{~g})$ were captured from late April through early December.

\section{Growth and Reproduction}

Repeated captures of individuals were recorded only on the large prairie grid; 8 mice were captured 2 times, 3 captured 3 times, and 1 captured 4 times. Only a male captured 4 times was recorded in 2 different years, whereas the other 11 mice were captured a few weeks apart in the same year. The male pocket mouse trapped in 2 different years weighed $29 \mathrm{~g}$ at first capture on 31 August and reached $46.5 \mathrm{~g}$ on 10 May the following year. Two other individuals weighing 25-26 g at first capture reached body masses of $43.5 \mathrm{~g}$ and $48.5 \mathrm{~g}$ by autumn of the same year. Mean gain in body mass per week was $1.72 \mathrm{~g} \pm 0.34$ $(n=13)$; those gains were similar for males (1.70 $\mathrm{g} \pm 0.41 ; n=6)$ and females (1.73 $\mathrm{g} \pm$ $0.34 ; n=7)$. Number of weeks between observations (range 2-7 weeks) did not significantly affect the gain per week $\left(R^{2}=0.012\right.$; $\left.F_{1,12}=0.12, P=0.74\right)$. In contrast, 2 large males ( $\sim 80 \mathrm{~g}$ in mid- and late spring) actually lost $5 \mathrm{~g}$ of body mass in the $2-6$ weeks after initial capture. Thus, a mass near $80 \mathrm{~g}$ might represent the upper limit for hispid pocket mice.

A plot of body masses for all 98 captures of individuals against date of capture suggests 3 age classes of hispid pocket mice (Fig. 4). Recorded body masses ranged from 12-59 g during the first growing season of life, from 35-72 g during the second, and from 74-81 g during the third. The regression line fitted to the first age class of the composite group suggested a lower growth rate $\left(\sim 1\right.$ g per week; $R^{2}$ $\left.=0.29 ; F_{1,73}=29.7, P<0.0001\right)$ compared to growth rates for individuals with repeated captures. Likewise, the second age class of the composite group exhibited a growth rate of $\sim 1$ g per week $\left(R^{2}=0.74 ; F_{1,19}=52.1, P<\right.$ $0.0001)$. Pocket mice likely lose $5-15$ g of mass during torpor over the winter period (Fig. 4).

Only one of the females in our study was pregnant when captured (on 9 May). However, small mice (10-25 g; body masses corresponding to juveniles) were captured over a period of $>2$ months (mid-June to late 


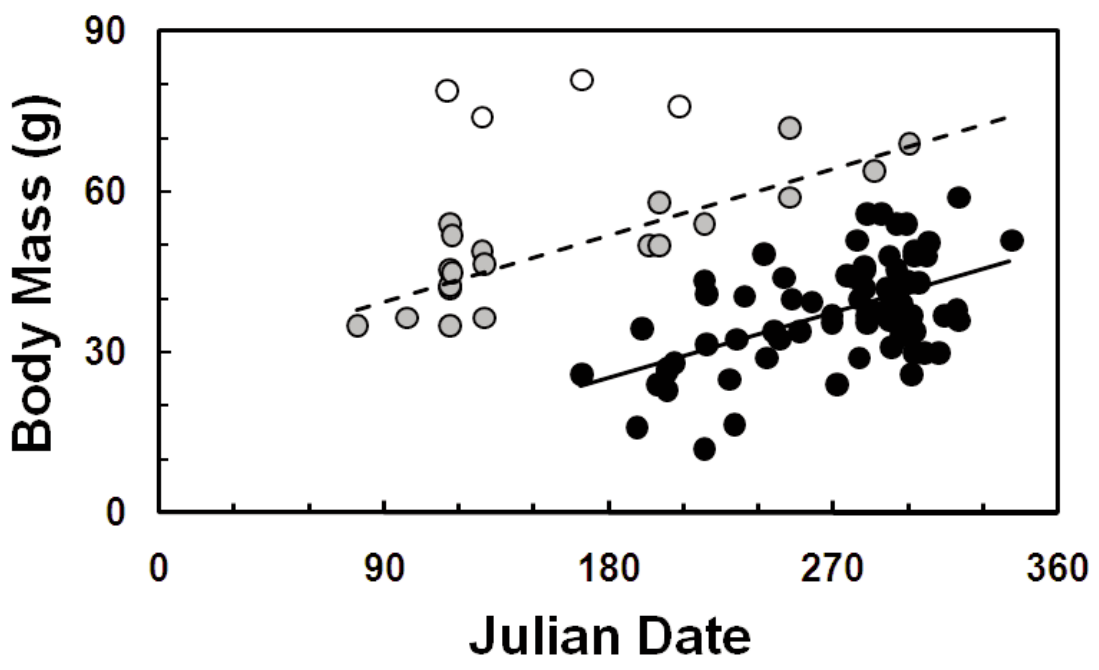

Fig. 4. Distribution of body sizes of hispid pocket mice (Chaetodipus hispidus) active aboveground through time (Julian date) on Konza Prairie Biological Station, Kansas, from autumn 1981 through spring 2011. Black circles represent individuals in age class 1 (hypothesized to be born in first growing season; 12-59 g), gray circles in age class 2 (hypothesized to be in their second growing season; 35-72 g), and open circles in age class 3 (hypothesized to be in their third growing season; 74-81 g). Lines suggest "potential" growth patterns for individuals in classes 1 (solid) and 2 (dashed) through annual cycle.

August); this suggests that females might give birth to $>1$ litter per year.

\section{Discussion}

Capture of only 55 individuals on $>1500$ prairie traplines over the past 30 years on Konza Prairie documents the low general abundance of pocket mice in this tallgrass prairie landscape. The Flint Hills, at the eastern edge of its range, generally has a limited number of suitable sites for hispid pocket mice (McMillan et al. 1999). This mouse typically has been associated with short, sparse vegetation and relatively open or sandy soils in arid grasslands (Choate and Fleharty 1975, Bee et al. 1981, Fleharty and Navo 1983, Paulsen 1988, Kaufman et al. 2000a). The tallgrass prairie at our study site represents a mesic environment and also lacks the sandy soils that this species prefers. Likewise, hispid pocket mice were widespread and at low abundances in a more arid environment (i.e., native mixed grass prairie), which had limestone breaks, but also lacked the sandy soils (Kaufman and Kaufman 2000). Furthermore, we observed that their abundance was highly variable $(C V=114 \%)$ in autumns. Temporal variation on Konza Prairie was almost twice as high as it was for pocket mice in mixed grass prairie in north-central Kansas $(\sim 65 \%$; Kaufman and Kaufman 2000). Although the latter was only a 5 -year study, the climatic conditions experienced during that study included a drought, a very wet year, and years of average precipitation.

We found no direct relationship between the number of pocket mice present and amount of precipitation (i.e., summer, growing season, or annual precipitation) that could explain the temporal variation in number. However, we found that the maximal number of hispid pocket mice that occurred in autumn was tightly limited by the amount of precipitation that occurred from winter to early autumn. As precipitation increased from 600 to $1150 \mathrm{~mm}$, the maximum number of individuals decreased from 4 to 0 in autumns. This negative response might be expected because this mouse inhabits arid sites, habitats, and geographic regions (Fleharty and Navo 1983, Paulsen 1988). Furthermore, heteromyid rodents, such as hispid pocket mice and Ord's kangaroo rats (Dipodomys ordii), were less affected by droughts than various cricetid rodents in southern Texas (Windberg 1998).

Physical conditions (e.g., topographic features and soil moisture) and vegetation (e.g., plant composition, standing vegetation, and plant litter) vary across the diverse, rolling 
landscape of the Flint Hills (e.g., Konza Prairie; Knapp et al. 1998b). Pocket mice were more abundant on rocky breaks and contiguous rocky hillslopes (collectively, slopes) than in uplands and lowlands, a pattern suggested by an earlier study on Konza Prairie (Kaufman et al. 1995). A similar pattern was found for this heteromyid farther west in Kansas where they occur in rocky breaks and upland sites (Kaufman and Kaufman 1989, 1990, Kaufman et al. 2000a). Hispid pocket mice on Konza Prairie were associated strongly with prairie slopes; standardized captures in slope prairie were $>10$ times that in lowland prairie and upland prairie on LTER Core lines. An impact of topography also was evident at the level of the entire survey line, as $96 \%$ of pocket mice recorded in autumn were captured on 8 sites where the breaks of hills were very rocky and associated slopes were steep, but these sites represented only $57 \%$ of the area sampled by traplines. Conversely, only $4 \%$ of pocket mice were recorded on the remaining 6 sites $(43 \%$ of area trapped), where slopes were shallow and few rocks occurred. Unexpectedly, abundance was similar in upland and lowland prairie, although uplands were more likely to have surface rocks. Apparently, the welldeveloped plant cover, which results from relatively high annual productivity in upland prairie (although less than in lowland; Knapp et al. 1998a), had a negative impact on its suitability for pocket mice. Finally, a strong association with slopes might relate not only to openness of the soil surface but also to an abundance of seeds (especially, forb seeds) in rocky breaks. Based on our general observations, several forb species are more likely present along breaks than elsewhere; this is true for a number of annual forbs that occur on carnivore diggings, which are preferentially located along breaks (Kaufman et al. 2005).

We expected that frequent fires and grazing by large ungulates would improve conditions for hispid pocket mice in tallgrass prairie, because both remove plant litter and standing dead vegetation and, thereby, open access to the soil surface. In contrast to our expectation, neither burning nor grazing had a significant effect on the abundance of these mice. Relative abundance of pocket mice was similar in burned and unburned prairie. One explanation of why we did not see a response to burning is that periodic and annual fire increase annual net primary productivity in the year of the fire if other environmental conditions are favorable (Knapp et al. 1998a). This effect would have occurred in our burned areas by the time that we sampled small mammals in the autumn. Relative to grazing effects, our sample size was sufficient to detect a strong effect of grazing on the abundance of pocket mice, if it was present. This lack of an effect is supported by the observation that only $25 \%$ of the stations where these mice were captured were associated with any grazing within the bison enclosure. This was unexpected because grazing not only opens the soil surface but increases plant diversity and some forbs compared to ungrazed areas (Hartnett and Fay 1998).

Hispid pocket mice on the LTER Core lines demonstrated a broad distribution across sites (64\% of Core sites) and through time (59\% of different autumns). The spatiotemporal distribution of individuals in LTER Core sites was not nested, in contrast to more abundant native species of small mammals on Konza Prairie (Kaufman et al. 2000b). Rather, pocket mice displayed a slightly "anti-nested" pattern of presence that lacked a spatiotemporal concentration because, even at sites that appeared to be preferred, pocket mice still were absent most of the time (Table 3). Furthermore, a majority of captures $(56 \%$ in Core sites) and autumns (67\% when pocket mice were present), and $46 \%$ of site-autumns involved only 3 Core sites. Interestingly, pocket mice were present at all 3 of these "preferred" sites in only one year and were present at only one of these 3 sites in the remaining autumns. Because of the association between pocket mice and rocky slopes, the pattern of spatial distribution was produced in part by the varying quality of slopes available at some Core sites. In contrast, the temporal distribution across these sites lacked any predictable pattern (e.g., no direct effect of precipitation on presence/absence, even if it was numerically limiting). Although pocket mice were somewhat spatially predictable, the rarity of these mice (and the seemingly inexplicable absences at preferred sites) combined with their temporal volatility render pocket mice unpredictable in a spatiotemporal context. The fact that Konza Prairie is on the edge of the species' range may contribute to its lack of on-site spatiotemporal predictability, as conditions are 
likely more unfavorable, in a larger geographic and climatic sense, than in the center of the species' distribution (e.g., Brown 1984, Brown et al. 1995, 1996, Murphy et al. 2006, Leuschner et al. 2009; cf. Sagarin and Gaines 2002).

\section{Aboveground Activity and Sex Ratio}

Hispid pocket mice were recorded from late March through early December. Only 2 individuals were captured in March, although our trapping typically began in early March (with occasional trapping in late February) and our effort was extensive. During this early spring trapping, pocket mice likely were still in seasonal torpor (occurs from late fall to early spring; Wang and Hudson 1970). Furthermore, these heteromyids store seeds in their burrows and periodically feed on these caches during winter, but they do not become active aboveground at these times (Jones et al. 1985). Our observed initiation of aboveground activity in late March generally agrees with earlier studies at this latitude (e.g., first capture on 3 April in north-central Kansas; Choate and Fleharty 1975). Likewise, hispid pocket mice in southwestern Kansas were not captured in cropland and native grassland in midMarch, although they were abundant in the same sites during the previous autumn (Fleharty and Navo 1983). On Konza Prairie, individuals captured relative to trapping effort increased from late March into early May, a pattern certainly related to aboveground activity following cessation of torpor.

It has been suggested that use of torpor is universal among species of Chaetodipus (French 1993). Our last capture of the calendar year, 7 December, agrees with cessation of aboveground activity and entry into torpor that typically occurs with cold weather in early winter at this latitude (e.g., 9 December; Choate and Fleharty 1975). Because our trapping efforts ended by mid-December, any aboveground activity because of atypical warm weather in winter (December-January) would not have been detected.

Sex ratio of hispid pocket mice differed seasonally. Sex ratios in spring and autumn deviated from a 1:1 ratio, which agrees with sex ratios in these seasons for small mammals that hibernate (e.g., ground squirrels; Michener 1984). For example, Richardson's ground squirrels have a male-biased sex ratio in early spring because males emerge from hiberna- tion and become active before females (Michener 1983). Likewise, 10 of 12 pocket mice active aboveground were males during late March-early May. In fact, no females were captured before 26 April, which resulted in only 1 of 11 mice captured before 1 May being a female. This strongly male-biased sex ratio suggests that males on Konza Prairie emerged from torpor earlier in spring than most, if not all, females. This might represent a male strategy to maximize opportunity for successful reproduction, as has been suggested for some species of Spermophilus (Michener 1984). In contrast to a male-biased sex ratio in spring, only $37 \%$ of 54 pocket mice captured during September-early December were males; this suggests that males reduced activity and entered torpor earlier than females. This autumnal pattern of female pocket mice prolonging aboveground activity longer than males also is observed in some sciurid rodents that hibernate (Michener 1984).

\section{Individual Attributes}

Little information is available for hispid pocket mice concerning patterns of body size, growth, reproduction, and behavior (Paulsen 1988, Eisenberg 1993, Jones 1993). Individuals on Konza Prairie ranged between $12 \mathrm{~g}$ and $81 \mathrm{~g}$; male and female adults did not differ significantly in body size. The body masses of the 5 largest individuals recorded on Konza Prairie (64-81 g) were greater than those reported for 7 pocket mice from the panhandle of Nebraska $(\bar{x}=48 \mathrm{~g}$, range $40-60 \mathrm{~g}$; Jones et al. 1983) and for the general ranges listed for adults in Kansas (range 40-60 g; Bee et al. 1981) and the Plains States (range: 35-60 g; Jones et al. 1985).

Three generalities are suggested by patterns of body mass of hispid pocket mice over an annual cycle on Konza Prairie. First, the majority of individuals weighed $30-55$ g, which is similar to the range reported by others (Bee et al. 1981, Jones et al. 1983, 1985). Second, small pocket mice $(<30 \mathrm{~g})$ were captured from 18 June to 28 October, which is a pattern that results from the period when young become independent and leave the nest $(\sim 1$ month after birth; Bee et al. 1981). Third, large individuals $(>55 \mathrm{~g})$ were infrequent but were captured throughout a similar period of the year as other adult pocket mice.

Only 12 hispid pocket mice were recaptured multiple times, so only a few observations of 
growth rates for specific individuals are possible. The number of grams gained per week was similar when we examined the change in body mass for individuals that had multiple captures $(1.7 \mathrm{~g})$ and that derived from our composite of individual body masses as viewed over time of year $(\sim 1 \mathrm{~g})$ given their body mass (3\%-4\% per week). In general, our data suggest a pattern of growth from birth (body mass at birth is unknown; Jones 1993) to $40-50 \mathrm{~g}$ by late fall, except for young born late in the growing season. Body masses of pocket mice emerging from torpor after their first winter were $>40 \mathrm{~g}$. Individuals can reach $65-70 \mathrm{~g}$ by late in their second autumn. We assume that the 2 males of $\sim 80 \mathrm{~g}$ in mid- to late spring were 20-24 months old, but possibly older. Finally, $80 \mathrm{~g}$ likely is near the maximum size for this heteromyid in eastern Kansas, and subsequent loss of mass by these individuals suggests they might have reached senescence (Slade 1995, McMillan et al. 1997).

We observed only one pregnant female, but the temporal distribution of pocket mice $<30$ $\mathrm{g}$ indicates that breeding events that produced these young mice occurred from mid-May through at least early autumn on Konza Prairie. The broad seasonal presence of young mice was consistent with the expectation that adult females can produce 2 or more litters per year given the length of the breeding season (Jones et al. 1983).

\section{Comments on Long-term Data}

The importance of long-term data sets is illustrated herein for rare to uncommon species of small mammals. For example, the preference of hispid pocket mice for slope habitat was beginning to emerge after 10 years of study of small mammals in native tallgrass prairie on Konza Prairie (Kaufman et al. 1995), but it was not statistically significant. Ten years is longer than the typical length of most ecological studies. Other investigators working on a long-term site often collect data on environmental factors that can be used to help explain patterns observed for the small mammal of choice. Furthermore, the accumulation of shorter studies in addition to long-term data sets in a focal area, such as Konza Prairie, allows us to explore patterns (e.g., aboveground activity, sex ratio, body mass, and others) that would not be possible with only short-term data. Short-term studies can provide substan- tial information for common species in the area of study, but they provide very little information for species that are widespread and low in abundance, such as the hispid pocket mouse (Paulsen 1988).

\section{ACKNOWLEDGments}

We thank D.E. Brillhart, B.K. Clark, E.J. Finck, R. Fristik, S.K. Gurtz, S.S. Bixler, R.S. Matlack, B.R. McMillan, A.W. Reed, and R.L. Rehmeier for assistance in collecting the information on small mammals on traplines and grids on Konza Prairie. J.J. Higgins provided statistical advice, and M. Knapp provided the precipitation data for the weather station in Manhattan, Kansas. Konza Prairie Biological Station is a tallgrass prairie preserve owned by The Nature Conservancy and managed by the Division of Biology at Kansas State University. The National Science Foundation through the Konza Prairie Long-Term Ecological Research Project supported this project from 1981 to present. Support for the $24 \times 24$ prairie grid research was provided by the National Science Foundation (BSR-8307571) to DWK, and monies from the Kansas Agricultural Experiment Station provided partial support for remaining projects on Konza Prairie. The Division of Biology provided financial support for graduate students over the past 30 years. This is contribution number 12-374-J from the Kansas Agricultural Experiment Station, Kansas State University, Manhattan.

\section{Literature Cited}

Armstrong, D.M. 1972. Distribution of mammals in Colorado. Monograph, University of Kansas, Museum of Natural History 3:1-415.

Atmar, W., And B.D. Patterson. 1995. The nestedness temperature calculator: a visual BASIC program [online]. Available from: http://www.fieldmuseum.org/ research collections/zoology/nested.htm

Bee, J.W., B.E. Glass, R.S. Hoffmann, and R.R. PatterSON. 1981. Mammals in Kansas. University of Kansas Publications, Museum of Natural History, Public Education Series 7:1-300

BLAIR, W.F. 1937. The burrows and food of the prairie pocket mouse. Journal of Mammalogy 18:188-191.

Brillhart, D.E., G.A. Kaufman, and D.W. Kaufman. 1995. Small-mammal use of experimental patches of tallgrass prairie: influence of topographic position and fire history. Pages 59-65 in D.C. Hartnett, editor, Proceedings of the 14th North American Prairie Conference: Prairie Biodiversity. Kansas State University, Manhattan.

Brown, J.H. 1984. On the relationship between abundance and distribution of species. American Naturalist 124:255-279. 
Brown, J.H., D.W. Mehlman, and G.C. Stevens. 1995 Spatial variation in abundance. Ecology 76:2028-2043.

Brown, J.H., G.C. Stevens, and D.M. Kaufman. 1996. The geographic range: size, shape, boundaries, and internal structure. Annual Review of Ecology and Systematics 27:597-623.

Choate, J.R., and E.D. Fleharty. 1975. Synopsis of native, recent mammals of Ellis County, Kansas. Texas Tech University, Occasional Papers of the Museum 37:1-80.

Clark, B.K., and D.W. Kaufman. 1990. Short-term responses of small mammals to experimental fire in tallgrass prairie. Canadian Journal of Zoology 68: 2450-2454.

EisenberG, J.F. 1993. Ontogeny. Pages 479-490 in H.H. Genoways and J.H. Brown, editors, Biology of the Heteromyidae. American Society of Mammalogists, Special Publication No. 10:1-719.

Finck, E.J., D.W. Kaufman, G.A. Kaufman, S.K. Gurtz, B.K. Clark, L.J. McLellan, and B.S. Clark. 1986. Mammals of the Konza Prairie Research Natural Area, Kansas. Prairie Naturalist 18:153-166.

FleharTy, E.D., AND K.W. Navo. 1983. Irrigated cornfields as habitat for small mammals in the sandsage prairie region of western Kansas. Journal of Mammalogy 64:367-379.

Freeman, C.C. 1998. The flora of Konza Prairie: a historical review and contemporary patterns. Pages $69-80$ in A.K. Knapp, J.M. Briggs, D.C. Hartnett, and S.L. Collins, editors, Grassland dynamics: long-term ecological research in tallgrass prairie. Oxford University Press, New York, NY.

French, A.R. 1993. Physiological ecology of the Heteromyidae: economics of energy and water utilization. Pages 509-538 in H.H. Genoways and J.H. Brown, editors, Biology of the Heteromyidae. American Society of Mammalogists, Special Publication No. 10:1-719.

Hartnett, D.C., and P.A. Fay. 1998. Plant populations: patterns and process. Pages 81-100 in A.K. Knapp, J.M. Briggs, D.C. Hartnett, and S.L. Collins, editors, Grassland dynamics: long-term ecological research in tallgrass prairie. Oxford University Press, New York.

Jones, J.K., Jr., D.M. Armstrong, and J.R. Chonte. 1985. Guide to mammals of the Plains States. University of Nebraska Press, Lincoln, NE.

Jones, J.K., JR., D.M. Armstrong, R.S. Hoffmann, AND C. JonEs. 1983. Mammals of the northern Great Plains. University of Nebraska Press, Lincoln, NE.

JonEs, W.T. 1993. The social systems of heteromyid rodents. Pages 575-595 in H.H. Genoways and J.H. Brown, editors, Biology of the Heteromyidae. American Society of Mammalogists, Special Publication No. 10:1-719.

Kaufman, D.M., G.A. Kaufman, and D.W. Kaufman. $2000 \mathrm{~b}$. Faunal structure of small mammals in tallgrass prairie: an evaluation of richness and spatiotemporal nestedness. Pages 47-70 in J.R. Choate, editor, Reflections of a naturalist: papers honoring Professor Eugene D. Fleharty. Fort Hays Studies, Special Issue 1, Fort Hays State University, Hays, KS.

Kaufman, D.W., and E.D. Fleharty. 1974. Habitat selection by nine species of rodents in north-central Kansas. Southwestern Naturalist 18:443-452.

Kaufman, D.W., and G.A. Kaufman. 1989. Nongame wildlife management in central Kansas: implications of small mammal use of fencerows, fields, and prairie.
Transactions of the Kansas Academy of Science 92:198-205.

1990. Small mammals of wheat fields and fallow wheat fields in north-central Kansas. Transactions of the Kansas Academy of Science 93:28-37.

Kaufman, D.W., G.A. Kaufman, and B.K. Clark. 2000a. Small mammals in native and anthropogenic habitats in the Lake Wilson area of north-central Kansas. Southwestern Naturalist 45:45-60.

Kaufman, D.W., G.A. Kaufman, and E.J. Finck. 1993. Small mammals of wooded habitats of the Konza Prairie Research Natural Area, Kansas. Prairie Naturalist 25:27-32.

Kaufman, D.W., S.K. Peterson, R. Fristik, and G.A. KaUfMan. 1983. Effect of microhabitat features on habitat use by Peromyscus leucopus. American Midland Naturalist 110:177-185.

Kaufman, G.A., AND D.W. Kaufman. 2000. Temporal and spatial variation in a small mammal community: an example from the mixed-grass prairie in Kansas. Pages 147-163 in J.R. Choate, editor, Reflections of a naturalist: papers honoring Professor Eugene D. Fleharty. Fort Hays Studies, Special Issue 1, Fort Hays State University, Hays, KS.

Kaufman, G.A., D.W. Kaufman, D.E. Brillhart, and E.J. FincK. 1995. Effect of topography on the distribution of small mammals on the Konza Prairie Research Natural Area, Kansas. Pages 97-102 in D.C. Hartnett, editor, Proceedings of the 14th North American Prairie Conference: Prairie Biodiversity. Kansas State University, Manhattan, KS.

Kaufman, G.A., D.W. Kaufman, and E.J. Finck. 1988. Influence of fire and topography on habitat selection by Peromyscus maniculatus and Reithrodontomys megalotis in ungrazed tallgrass prairie. Journal of Mammalogy 69:342-352.

Kaufman, G.A., S.D. Kocher, and D.W. Kaufman. 2005. Distribution of carnivore burrows in a prairie landscape. Great Plains Research 15:15-29.

KnapP, A.K., J.M. Briggs, J.M. Blair, and C.L. Turner, 1998a. Patterns and controls of aboveground net primary production in tallgrass prairie. Pages 193-221 in A.K. Knapp, J.M. Briggs, D.C. Hartnett, and S.L. Collins, editors, Grassland dynamics: long-term ecological research in tallgrass prairie. Oxford University Press, New York, NY.

Knapp, A.K., J.M. Briggs, D.C. Hartnett, and S.L. Collins, EDitors. 1998b. Grassland dynamics: long-term ecological research in tallgrass prairie. Oxford University Press, New York, NY.

KNapP, A.K., And T.R. SEastedt. 1998. Grasslands, Konza Prairie, and long-term ecological research. Pages 3-15 in A.K. Knapp, J.M. Briggs, D.C. Hartnett, and S.L. Collins, editors, Grassland dynamics: long-term ecological research in tallgrass prairie. Oxford University Press, New York, NY.

Leuschner, C., B. Köckemann, and H. Buschmann. 2009. Abundance, niche breadth, and niche occupation of central European tree species in the centre and at the margin of their distribution range. Forest Ecology and Management 258:1248-1259.

McMillan, B.R., and D.W. Kaufman. 1994. Differences in use of interspersed woodland and grassland by small mammals in northeastern Kansas. Prairie Naturalist 26:107-116.

McMillan, B.R., D.W. Kaufman, and G.A. Kaufman. 1999. Rare species of small mammals in northeastern 
Kansas tallgrass prairie. Pages 120-126 in J.T Springer, editor, Proceedings of the 16th North American Prairie Conference: The Central Nebraska Loess Hills Prairie. University of Nebraska at Kearney, Kearney, NE.

McMillan, B.R., G.A. Kaufman, and D.W. Kaufman 1997. A case of senescence for the white-footed mouse. Prairie Naturalist 42:236-237.

Michener, G.R. 1983. Spring emergence schedules and vernal behavior of Richardson's ground squirrels: why do males emerge from hibernation before females? Behavioral Ecology and Sociobiology 14: $29-38$

1984. Age, sex, and species differences in the annual cycles of ground-dwelling sciurids: implications for sociality. Pages 81-107 in J.O. Murie and G.R. Michener, editors, The biology of grounddwelling squirrels. University of Nebraska Press, Lincoln, NE.

Moulton, M.P., J.R. Choate, S.J. Bissell, and R.A. Nicholson. 1981. Association of small mammals on the central high plains of eastern Colorado. Southwestern Naturalist 26:53-57.

Murphy, H.T., J. VanDerWaL, and J. Lovett-Doust. 2006. Distribution of abundance across the range of eastern North American trees. Global Ecology and Biogeography 15:63-71.

Oviatt, C.G. 1998. Geomorphology of Konza Prairie. Pages 35-47 in A.K. Knapp, J.M. Briggs, D.C. Hart- nett, and S.L. Collins, editors, Grassland dynamics: long-term ecological research in tallgrass prairie. Oxford University Press, New York, NY.

Paulsen, D.D. 1988. Chaetodipus hispidus. Mammalian Species 320:1-4.

Sagarin, R.D., And S.D. Gaines. 2002. The 'abundant centre' distribution: to what extent is it a biogeographic rule? Ecology Letters 5:137-147.

SChMidLY, D.J., K.T. Wilkins, AND J.N. DERR. 1993. Biogeography. Pages 319-356 in H.H. Genoways and J.H. Brown, editors, Biology of the Heteromyidae. American Society of Mammalogists, Special Publication No. 10:1-719.

SLADE, N.A. 1995. Failure to detect senescence in persistence of some grassland rodents. Ecology 76: 863-870.

WANG, L.C., AND J.W. Hudson. 1970. Some physiological aspects of temperature regulation in the normothermic and torpid hispid pocket mouse, Perognathus hispidus. Comparative Biochemistry and Physiology 32:275-293.

WindBerg, L.A. 1998. Population trends and habitat associations of rodents in southern Texas. American Midland Naturalist 140:153-160.

ZAR, J.H. 1974. Biostatistical analysis. Prentice-Hall, Inc., Englewood Cliffs, NJ.

Received 5 July 2011 Accepted 26 April 2012 